DOI: https://doi.org/10.24297/jam.v20i.9137

\title{
Possibilities of Preparing Pupils for Proof Problems of Synthetic Plane Geometry Solvable by Deductive Methods
}

Vojtěch Zlámal

Ph.D. student, Faculty of Science of the Palacky University in Olomouc, Czech Republic

\begin{abstract}
Proof problems, especially the ones of the synthetic plane geometry solvable by deductive methods, play a significant role in mathematical education and due to their demanding principle also in the above-standard education including mathematical competitions. Therefore, the issue of preparing pupils for solving the proof problems is very important. This study aimed to find out if the contemporary state of the system of pupils' preparation for synthetic plane geometry proof problems is sufficient enough for the mentioned purpose. From the full set of schools of the Czech Republic, there were 14 schools identified as the successful ones based on the results of the national round of the Mathematical Olympiad. These schools were asked questions about literature used for pupils' preparation and the publications named in the answers were then deeply inspected. The results showed a narrow range of the literature used by the schools and the didactic-methodical inspection of stated literature detected considerable space for improvements which led the author to the main theme of his dissertation.
\end{abstract}

Keywords: deductive methods, problem-solving, proof problems, pupils' preparation, synthetic plane geometry.

1

Introduction

Although the area of synthetic plane geometry is included in the curricular documents of the educational system of the Czech Republic ${ }^{1}$ as an integral part of education, the focus of this article will be the area of above-standard teaching and preparation of secondary school pupils for mathematical competitions. In the field of synthetic plane geometry, secondary school pupils encounter three types of mathematical problems. These are construction, determination and proof problems (Vyšín, 1972). The theme of the research is the role of the proof problems; therefore, the next text is dealing only with them. It is characteristic of these proof problems that pupils can solve them by computational or deductive methods. The computational methods of proofs are based on the calculation of a specific numerical value, while deductive methods are based on the basic properties and position of the specified geometric shapes (Parker, 2008). However, it is not possible to say that the problems are always solvable in both ways, so the following text will only deal with the proof problems solvable by deductive methods.

The plane geometrical problems, whose solution or part of their solutions is a proof guided by deductive methods, are often encountered by pupils in various mathematical competitions (Mathematical Olympiad, 2020). These problems have their place here because these are problems that are demanding of the cognitive abilities of solvers (these problems are directed to the highest level of Bloom's taxonomy - creation), and it is the demanding problems that allow us to identify the most gifted students. In the Czech Republic ${ }_{\text {" }}$ it is possible to take as a benchmark the competition Mathematical Olympiad ("Matematická olympiáda”), which has been held annually since 1951 (Yearbook of Mathematical Olympiad, 1952-). This competition involves primary and

1 In the period from 2009 the new curricular documents, the so-called "RVP", are entering into force. These new documents always come into force for the first grade of the specific school. From 2009 to 2012, teaching coexisted according to the old and the new curricular documents. Since 2012, teaching in schools has been organized exclusively according to the "RVP". 
secondary school pupils who are divided into categories according to the year they are in at the school. The Mathematical Olympiad is a competition where you can move up; school, district and regional rounds are organized. Only in the highest category " $\mathrm{A}$ " the national round is organized. Category A is intended for pupils of the third and fourth year of secondary schools. Due to the demands and complexity of the problems in category " $A$ ", the competitors in this category are usually pupils who participated in the Mathematical Olympiad in previous years (and thus in lower categories). Long-term and systematic preparation is required to prepare pupils for participation in the higher categories and rounds of the Mathematical Olympiad. Although pupils can prepare on their own, the responsibility for their preparation is very often taken over by the school and the teachers of mathematics. This study therefore focuses on the effective possibilities, ways and forms of preparation of pupils for the specified type of problems in schools.

The issue of preparing pupils for proof problems of synthetic plane geometry that appear in the Mathematical Olympiad can be viewed from different sides. The first aspect involves organizational possibilities and forms of preparation. These are mainly preparations within standard lessons, above-standard preparation in the form of school clubs, etc., or self-study. In the course of preparation in standard lessons, teachers can stimulate selected pupils with voluntary problems or by adding non-standard elements to the discussed problems. In the school clubs, it is usually a direct preparation for a particular mathematical competition. Self-study then allows pupils to deal with selected topics according to their interests.

Another aspect involves the availability and quality of literature that pupils can use in their preparation. If the proof problem presented in the literature is intended to be an example of a solution method and also an inspiration for solving similar problems, it is appropriate to provide this example problem with a didacticmethodical commentary (note) that will help the pupil to include the individual steps of the proof in the internal thought system. If the pupil uses the given publication in the course of long-term preparation, these didacticmethodical comments must be then appropriately systematized.

Although pedagogic research in the Czech Republic involves field of above-standard education, there is no relevant study considering didactic-methodical aspect. Therefore, the aim of the study was to explore the possibilities of preparing pupils for the proof problems of secondary school synthetic plane geometry and inspect used publications/materials in consideration of didactic-methodical aspects.

The following questions can provide a basic insight into the issue:

1. What possibilities are used to prepare pupils of successful schools for mathematical competitions?

2. What materials are used for teaching synthetic plane geometry in standard lessons at these schools?

3. What materials are used in other activities of those schools that are set to prepare pupils for the competition problems of synthetic plane geometry?

4. To what extent and form are the proof problems represented in the materials used by those schools for the preparation of pupils for the problems of synthetic plane geometry in mathematical competitions?

Note. Within question 4, the research deals with the mentioned didactic-methodical aspect of the given problems.

As of insufficiency of current research in didactic-methodical approach in the above-mentioned field, this research could be an opening study for a possible new attitude of creation appropriate study materials. 
2 Methodology

\subsection{General Background}

Based on the above-mentioned research questions, the next procedure is divided into two stages. In the first stage the answers to questions 1 to 3 are found out. The selection of successful schools (research sample) and the compilation of a research tool for finding out the answers to the questions are the prerequisites for the success of the first stage. The next second stage focuses on analysing the teaching materials that result from the results of the first stage.

\subsection{Sample}

The result lists of the national round of the Mathematical Olympiad category A, from the year 2011 to 2020, are the basis for determining the research sample of successful schools. The selected category and the round are chosen on the basis of the above-mentioned nature of the competition and also on the basis of the availability of data. This period of time was chosen to reflect the period of setting new curricular documents in the Czech Republic in the years that fall into the competition category A, in order that the starting conditions for schools in the possibilities of preparing pupils would be comparable.

The schools can be considered as successful if their pupils participated in the absolute majority of the assessed national rounds. This criterion was chosen to the detriment of the first considered average number of pupils of the school in each national round, as it more expresses the stability of preparation of the pupils. The criterion of the average number of pupils is also more prone to extreme values, that is one-off successes of a large number of pupils of the school, which is irrelevant in terms of long-term preparation. It must be further stressed that the criterion of the average number of pupils can put small schools at a strong disadvantage. In their case, for example even the permanent participation of one pupil in each national round can indicate a high-quality preparation. The chosen criterion of the total number of participations of pupils of the school eliminates these shortcomings.

\subsection{Instrument and Procedures}

When choosing a research tool to find out answers to research questions 1 to 3 , it was also necessary to take into account the current state of school bureaucracy. Schools are currently overwhelmed with all sorts of questionnaires and forms, so it was not advantageous at this stage to choose the form of the questionnaire, as this would reduce the likelihood of return. After consultation with representatives of different types of schools, a form of personalised e-mail was chosen and it was sent to the address of the teacher, who has the competence to prepare pupils for mathematical competitions at the school or ensures mathematical education at the school overall. This e-mail contained just research questions 1 to 3 which were concretized to the particular school. From the answers to questions 2 and 3 a list of publications with a frequency of their use was composed whereas these publications were further analysed.

\subsection{Data Analysis}

The collected data were registered in the form of tables and processed by the spreadsheet tools. A table was used to record the answers to the first question, in which the rows represented the answers from each school and the columns represented the possibilities of preparing pupils used at the particular school. The coding of the answers was $T$ (the school uses the possibility of preparation), $F$ (the school does not use the possibility). Tables were also used to record answers to questions 2 to 3, the rows of which corresponded to the answers from each school again, and the columns marked the individual publications that appeared in the answers. The record of individual responses for the single publication was encoded $T$ (the school uses the publication) and $F$ (the school does not use the publication). Since the data can also be viewed from a summary point of view, the data were summarized into a single complex table for the purpose of visualization and interpretation. Whereas the collected data is simple, the bar and pie charts and the pivot tables were used for subsequent interpretation. 
The subsequent processing of the publications which are used included the analysis of mathematical theorems and proof problems that included deductive methods of solution. If the publication also contained parts that did not concern the subject of this study (e.g. construction and determination problems), those parts were not included in the analysis. It was assessed in the mathematical theorems whether there was the presence of proof and whether the proof contained a didactic-methodical commentary. The proof problems were distinguished into solved and unresolved ones. It was assessed in the solved problems whether they contained didacticmethodical commentary, and in the unresolved ones, whether they contained didactic-methodical help.

Note: Although this is not the aim of this study, it is also possible to analyse the geographical distribution of successful schools within the Czech Republic on the basis of the collected data of the statistics.

3

\section{Results and Discussion}

\subsection{Results}

Out of a total number of 116 schools whose pupils participated at least once in the national round in category A between 2011 and 2020, 14 successful schools were identified. In terms of the type of the school, only grammar schools were present within successful schools, while in the list of all schools, grammar schools represented $96.55 \%$ secondary vocational schools $2.59 \%$ and primary schools $0.86 \%$ (see Fig. 1).

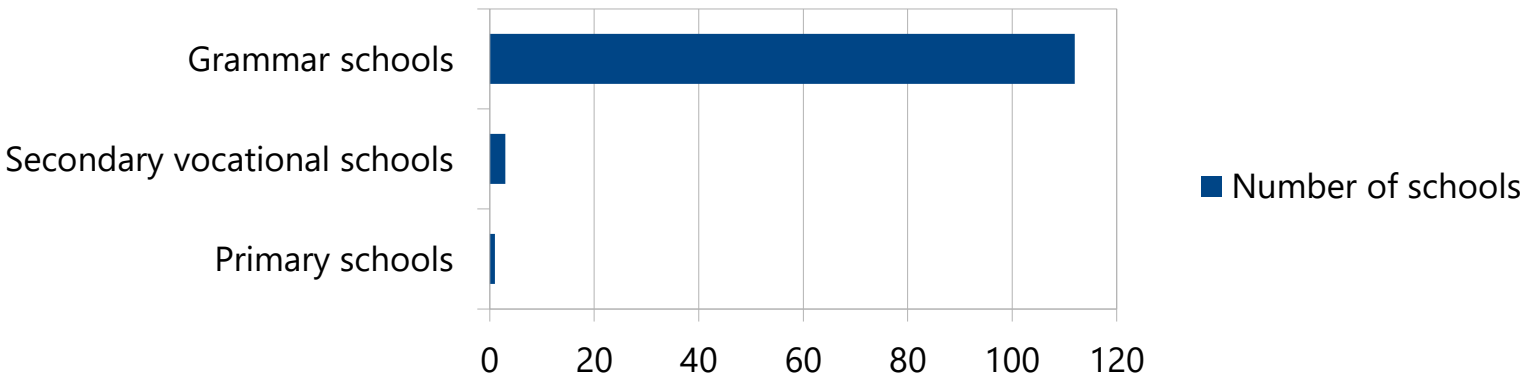

Figure 1. Type distribution of schools that have participated at least once in the national round of Mathematical Olympiad between 2011 and 2020

As to the geographical distribution of the schools within the Czech Republic, the Capital City of Prague (24 schools) was the most represented and the Karlovy Vary Region (2 schools) was the least represented. Among the successful schools, the Capital City of Prague (4 schools) was the most represented again. The total state is summarized in Fig. 2. 


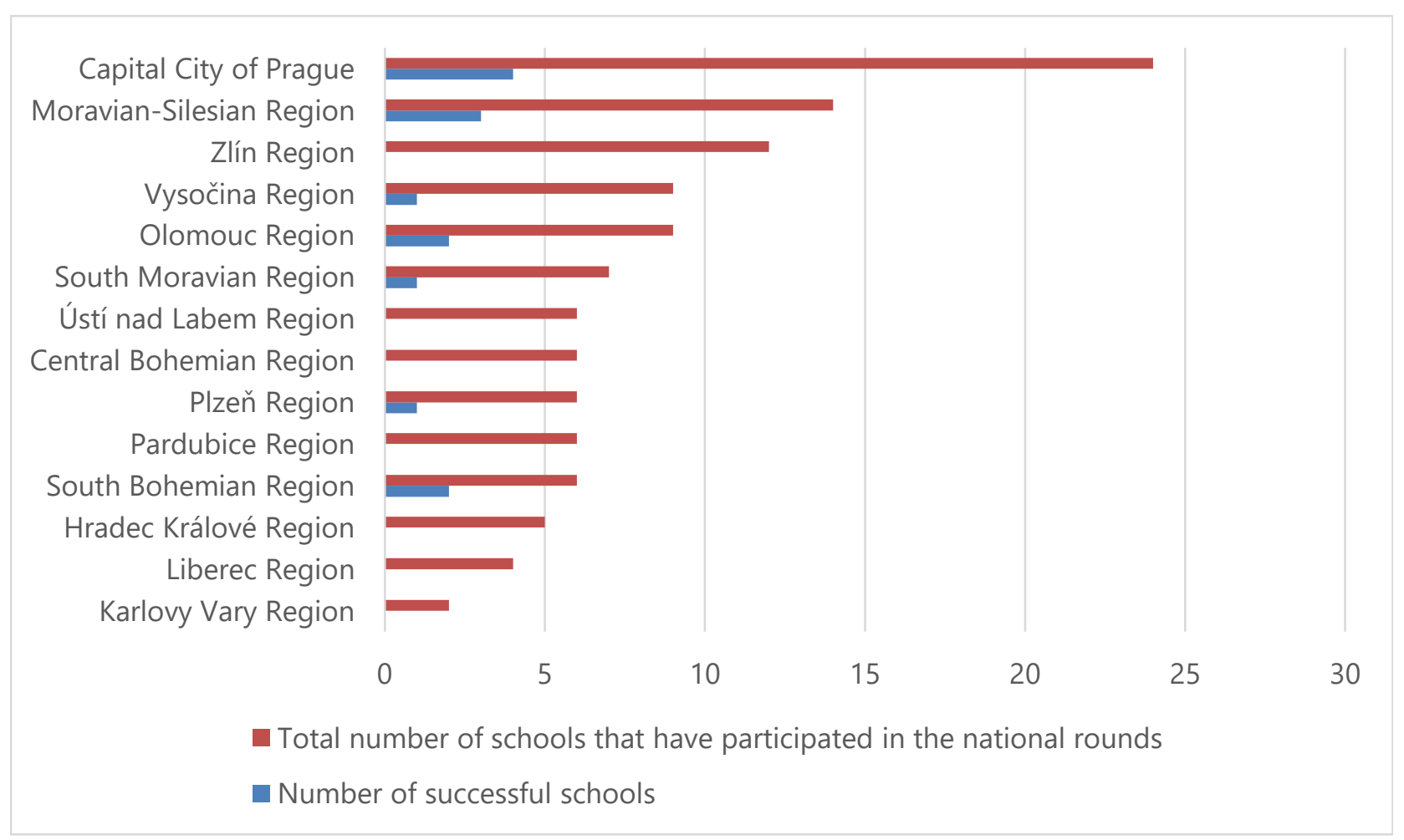

Figure 2. Regional distribution of the schools that have participated at least once in the national round of Mathematical Olympiad between 2011 and 2020

\subsubsection{First Stage Results}

The tables (and graphs based on them) were compiled from the answers to the questions that were sent out (return was $92.86 \%$ ). Figure 3 shows the use of preparations of pupils within the above-standard clubs/seminar (61.54\% of schools use this option). All schools have also confirmed that they are stimulating pupils in the context of standard lessons too. They also support and motivate them to self-study.

The school offers above-standard clubs/seminar

The school does not offer above-standard clubs/seminar

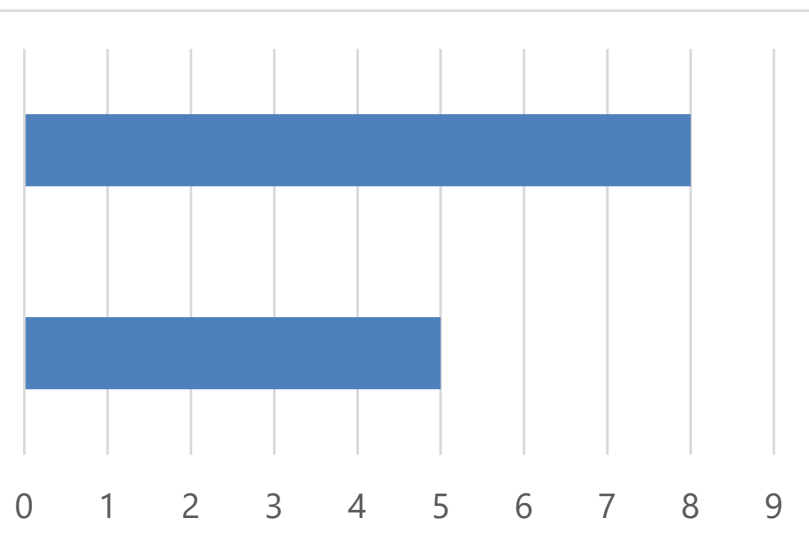

Number of schools

Figure 3. Number of successful schools offering above-standard clubs/seminar 
The answers to the second question are summarised in Fig. 4, which shows the frequency of use of individual publications within standard lessons at specific schools. It is clear here that in the standard lessons, most schools (84.62\%) use the textbook "Mathematics for grammar schools - Plane Geometry" (Pomykalová, 2000) published by Prometheus.

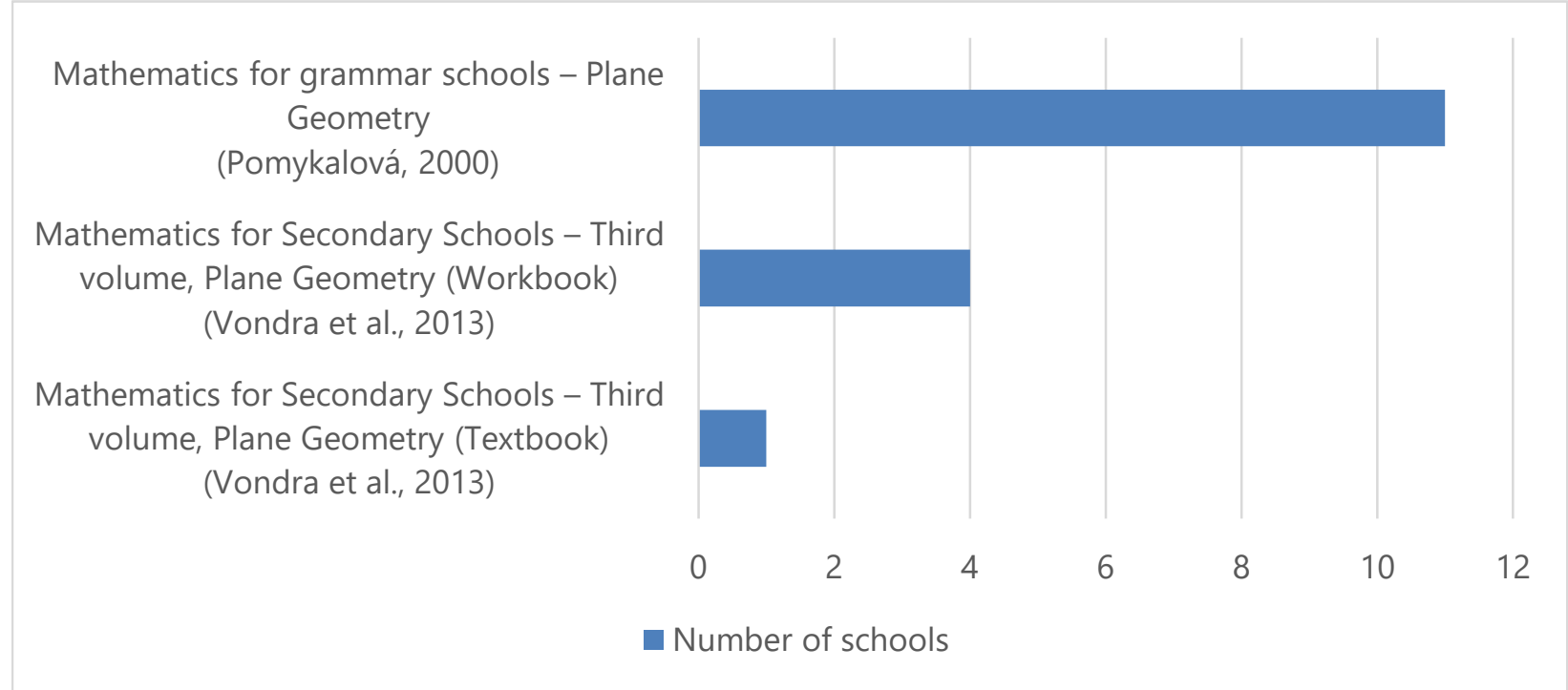

Figure 4. Use of publications in the mathematical lessons at the successful schools

Its alternative, the workbook "Mathematics for Secondary Schools - Third volume, Plane Geometry" (Vondra et al., 2013), is often used by schools as an additional text. This is evident from Table 1, which lists the number of schools using combinations of different publications. Only one school uses the textbook that belongs to the mentioned workbook. The schools did not mention any other publications in this question.

Mathematics for Grammar Schools - Plane Geometry (Pomykalová, 2000) [MfGS]

Mathematics for Secondary Schools - Third volume, Plane

Geometry (Textbook)

(Vondra et al., 2013) [MfSS-T]

Mathematics for Secondary Schools - Third volume, Plane

Geometry (Workbook)

(Vondra et al., 2013) [MfSS-W]
[MfGS] [MfSS-T] [MFSS-W]
1

Table 1. Number of schools using combinations of different publications in the mathematical lessons

As in the case of the second question, the answers to the third question are summarized in Fig. 5 . It shows the number of schools using different materials in the further preparation of pupils for the problems of synthetic plane geometry. The most frequently used option (38.46\% of schools) is the commented solutions of previous years of the Mathematical Olympiad (Mathematical Olympiad, 2020). The second option used is the serial publication "School of Young Mathematicians (1961-1988). Other materials, mainly in the form of exercise collections, were used in a minority. 


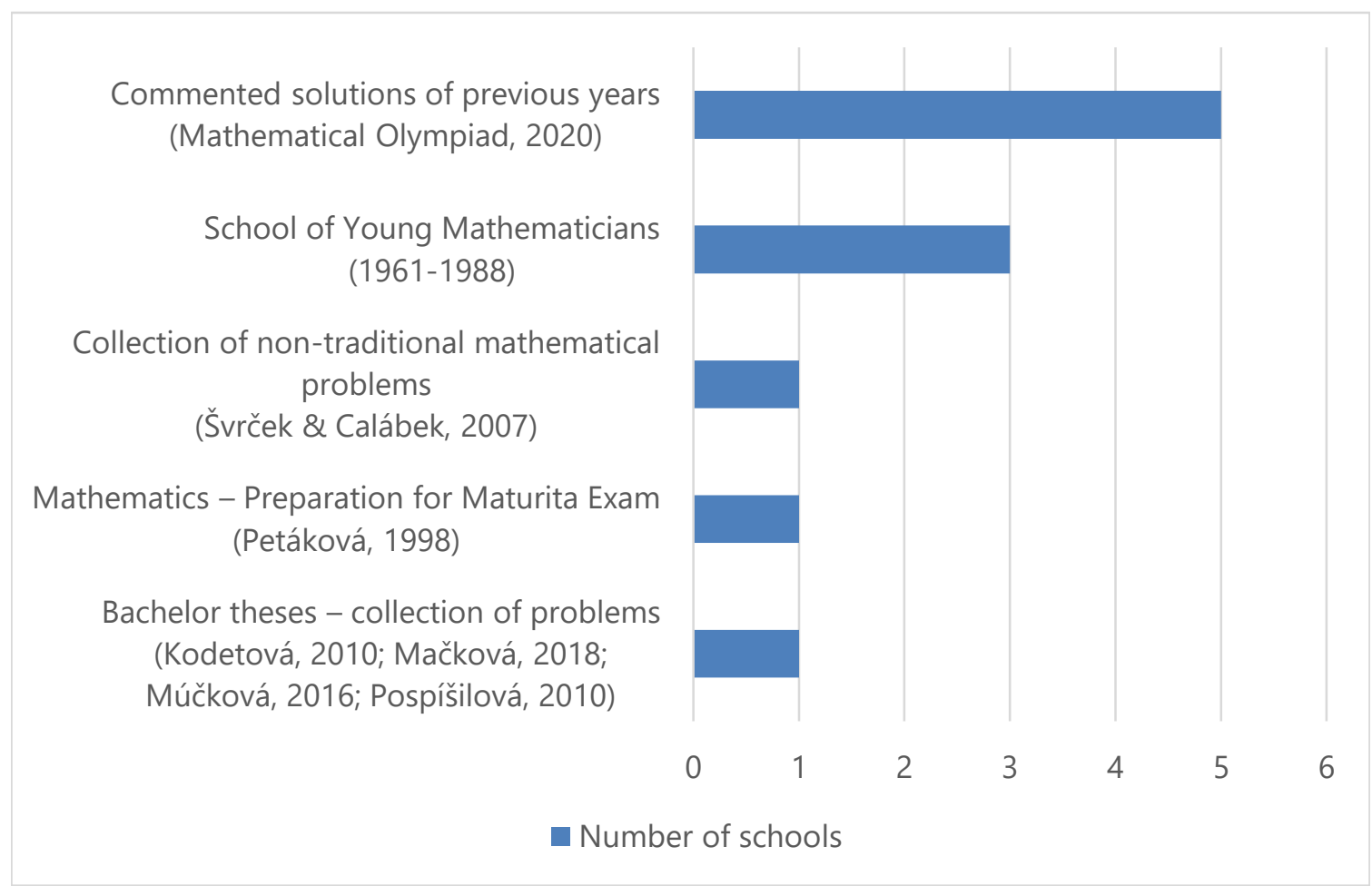

Figure 5. Use of publications in the pupils' preparation for the synthetic plane geometry proof problems at the successful schools

\subsubsection{Second Stage Results}

The publications that are used within standard lessons were analysed as it was mentioned above. Although the proofs are represented in the individual publications (as it is shown in Tables 2, 3 and 4), the materials that were examined do not contain systematic didactic-methodological comments or notes on the given proofs.

Proof problems with solution

[MfGS] [MfSS-T] [MfSS-W]

Number of those containing didactic-methodological

4

3

0

comments

0

0

0

Table 2. Number of solved synthetic plane geometry proof problems contained in stated publications

Proof problems without solution

[MfGS]

[MFSS-T]

[MfSS-W]

Number of those containing didactic-methodological

35

0

12

comments

Table 3. Number of unsolved synthetic plane geometry proof problems contained in stated publications

Theorems

[MfGS] [MfSS-T] [MfSS-W]

Number of those followed by proof

23

22

0

Number of those containing didactic-methodological

20

4

0

comments

Table 4. Number of synthetic plane geometry theorems contained in stated publications

For the publication "School of Young Mathematicians" (1961-1988) and for the commented solutions of individual problems of the Mathematical Olympiad (Mathematical Olympiad, 2020) which are used in the above- 
standard preparation of pupils by the schools, it was not possible, due to their nature, to create similar tables of statistical data. The analysis of these materials shows that they partly contain a didactic-methodical commentary, which is however not systematically conducted in its entirety.

These task collections contained only examples, not sentences and their proofs. Their analysis was therefore summarised in a single Table 5. It shows that the collections "Collection of Non-traditional Mathematical Problems" (Švrček \& Calábek, 2007), "Mathematics - Preparation for Maturita Exam" (Petáková, 1998) did not contain any didactic-methodological comments and that the collection of problems in the form of bachelor theses (Pospišilová, 2010), (Kodetová, 2010), (Múčková, 2016), (Mačková, 2018) contain these comments (even if only in the form of a classification of the means that were used). Other collections of problems were marked as "others" in the answers from the schools, so they could not be analysed.

\section{Proof problems with solution \\ Proof problems \\ without solution}

Mathematics - Preparation for

Maturita Exam

(Petáková, 1998)

Collection of Non-traditional

Mathematical Problems

(Švrček \& Calábek, 2007)

Bachelor thesis

(Pospíšilová, 2010)

Bachelor thesis

(Kodetová, 2010)

Bachelor thesis

(Múčková, 2016)

Bachelor thesis

(Mačková, 2018)

\author{
Number of those \\ containing didactic- \\ methodological \\ comments
}

0

0

4

5

3

3

Table 5. Number of synthetic plane geometry proof problems contained in stated collections of problems

\subsection{Discussion}

The basic overview shows that the schools (both successful and others) are not dislocated only in the capital city or specific region of the Czech Republic. The Mathematical Olympiad is therefore not discriminatory in terms of a school location. Furthermore, the well-known fact, that successful schools give the students above-standard care and support, is confirmed (the form of support is similar in all selected schools).

Although there is currently a number of math textbooks for secondary schools and other publications on the market, successful schools are somewhat conservative in this regard. In the case of the main textbook for standard lessons, they prefer the textbook "Mathematics for grammar schools - Plane Geometry" (Pomykalová, 2000), which was first published in 1993, and among the materials for further preparation of pupils the serial publication "School of Young Mathematicians" (1961-1988) from the second half of the 20th century is mentioned.

The analyses of individual textbooks have shown that although they are engaged in the proof problems of synthetic plane geometry solvable by deductive methods to a considerable extent, they are fundamentally lacking in didactic-methodological guidance. Those proofs and the proof problems are thus primarily used to include and link the content of the study into a whole. Their supporting role in preparing pupils for the competition proof problems of the Mathematical Olympiad cannot therefore be fully developed. The analysis of other supporting texts has shown that even in them a didactic-methodological approach is not satisfactory. 


\section{$4 \quad$ Conclusions}

This study revealed a weakness in the possibilities of preparing pupils for the proof problems of synthetic plane geometry, specifically in preparation for the Mathematical Olympiad. The materials that are used here cannot lead pupils to systematic and methodical preparation for this type of problems, as it is in the case of other areas, e.g. "Methods of solving mathematical problems I/II" (Kučera et al., 2001; Kučera et al., 2004) - in the fields of algebraic equations, inequalities, number theory and combinatorics. This situation thus opens up the possibility of trying to compile and supplement the appropriate material available not only to pupils and teachers of secondary schools, but also to university students who study teaching subjects.

\section{References}

Kodetová, M. (2010). Sbírka úloh z planimetrie [Problems in plane geometry] (Bachelor thesis, Masaryk University, Faculty of Science, Brno).

Kučera, R., Herman, J., \& Šimša, J. (2001). Metody řešení matematických úloh I (2nd ed.) [Methods of solving mathematical problems I]. Brno: Masaryk University.

Kučera, R., Herman, J., \& Šimša, J. (2004). Metody řešení matematických úloh II (2nd ed.) [Methods of solving mathematical problems II]. Brno: Masaryk University.

Mačková, P. (2018). Planimetrické výpočty $v$ príkladech [Planimetric calculations in solving problems] (Bachelor thesis, Masaryk University, Faculty of Science, Brno).

Matematická olympiáda [Mathematical Olympiad]. (2020). Retrieved from http://www.matematickaolympiada.cz

Múčková, M. (2016). Sbírka planimetrických úloh řešených pomocí shodností [Exercise book of plane geometry isometric mappings] (Bachelor thesis, Masaryk University, Faculty of Science, Brno).

Parker, T. (2008). Elementary geometry for teachers. Okemos: Sefton-Ash Publishing.

Petáková, J. (1998). Matematika - príprava k maturitě (1st ed.) [Mathematics - Preparation for Maturita Exam]. Prague: Prometheus.

Pomykalová, E. (2000). Matematika pro gymnázia: Planimetrie (4th ed.) [Mathematics for grammar schools Plane Geometry]. Prague: Prometheus.

Pospišilová, H. (2010). Sbírka úloh z planimetrie [Problems in plane geometry] (Bachelor thesis, Masaryk University, Faculty of Science, Brno).

Ročenka matematické olympiády na středních školách [Yearbook of Mathematical Olympiad]. (1952-). Prague: Státní pedagogické nakladatelství.

Škola mladých matematiků [School of Young Mathematicians]. (1961-1988). Prague: Státní pedagogické nakladatelství.

Švrček, J., \& Calábek, P. (2007). Sbírka netradičních matematických úloh (1st ed.) [Collection of non-traditional mathematical problems]. Prague: Prometheus.

Vondra, J., Gazárková, D., Melicharová, S., Vokřinek, R., \& Květoňová, M. (2013). Matematika pro střední školy Třetí díl (1st ed.) [Mathematics for secondary schools - Third volume]. Brno: Didaktis.

Vyšín, J. (1972). Metodika řešení matematických úloh (2nd ed.) [Methodology of problem solving]. Prague: Státní pedagogické nakladatelství.

\section{Conflicts of Interest}

The author declares no conflict of interests. 